\title{
Pildi sisse minek. Talletades ja uurides aega, ühiskonda, inimesi ja ennast...
}

\author{
Eda Kalmre
}

Uuenäoline folkloristika, mis maailmas, aga eriti Ameerika Ühendriikides 1960. aastatel arenes, tõstis varasema tekstikeskse uurimise kõrval esile ka inimkäitumist uuriva perspektiivi rahvaluuleteaduses. Sellega kaasnes välitööde tähtsustumine folkloristikas, sest uurijate tööd baseerusid eeskätt oma kogutud materjalidele ja välitöödel tehtud vaatlustele ning saadud kogemustele. (Vt Siikala 2007.) See asjaolu tõstis välitööd ja folkloristi enda isiku ja oskused kultuuride vahendaja, koguja ja analüüsijana tähelepanu keskmesse.

Folkloristlikke ja etnoloogilisi välitöid hakati nägema kui omamoodi pildi sisse minekut, kas siis füüsilisel moel linna- või külakultuuri inimeste olmesse ja eludesse või siis tänapäeva inimeste suhtlusvõrgustikesse läbi interneti keskkondade erinevate arvamusruumide. Olles ajutiselt selle pildi osa, tekivad siseneja ja olijate vahel erilised suhted, mis mõjutavad sisenejat ning tema arusaamist sellest maailmast. Teisalt mõjutab ka siseneja ise oma tausta, soovide ja käitumisega seda pilti, kuhu ta on sattunud. Ehk teisisõnu: selles pildis, mis kusagile uurimistöösse või arhiivi talletub, on osa nii uuritava kui uurija maailmast ehk nende kahe suhtlusest sündinud materjal. 
Reflekseerimine ja välitööde mõtestamine on saanud üha rohkem välitööde osaks ning selle vahendamine on olnud folkloristika kui distsipliini osa. Juba vähemalt viisteist aastat on Akadeemiline Rahvaluule Selts pidanud välitööde teemalisi konverentse kas siis sügiskonverentsi või kogumiskonverentsi nime all. Tegelikkuses ulatub suviste välitööde kajastamise ajalugu palju kaugemale tagasi. Näiteks 1970.-1980. aastail tehti seda tavaliselt ühe-kahe ettekandega sügisesel Emakeele Seltsi rahvaluule sektsiooni kõnekoosolekul. Neil aegadel kutsuti välitöid ekspeditsioonideks ja need tähendasid tavapäraselt kirjandusmuuseumi rahvaluule osakonna või Tartu ülikooli rahvaluule üliõpilaste väljasõitu kuskile Eestimaa kihelkonda ning seal läbi viidud frontaalset küsitlust, s.t võimalikult kõigi rahvaluuleliikide kogumist (vt Kolk ja Laugaste 1963).

1990. aastail tekkisid uued võimalused ja mitmekesistusid folkloristide uurimisalad. See tingis ka välitööde arvukuse ja muutunud iseloomu. 2000. aastate algusesse jäänud Kullamaa, Paistu ja Sõrve poolsaare kihelkondade välitööd olid rahvaluule arhiivis ühed viimased korralised frontaalsele küsitlusele suunatud kogumisretked Eestis. Sealt edasi on välitööd toimunud üldjuhul projektipõhiselt ning olnud enamasti suunatud mingi kindla teema (kohapärimus, koolipärimus jm), kogukonna (nt Siberi eestlased, perefoorum internetis) või žanri (lühivormid, naljad, kuulujutud, muistendid jt) kogumisele. Paljude välitööde eesmärgiks on olnud kas uurimustöö või ka näiteks kohalik kommenteeritud tekstiväljaanne.

Välitöid tehaksegi tänapäeval nii päris maailmas kui ka virtuaalsetes kohtades, ning sügiseste konverentside üks eesmärke on välitöid tegevad folkloristid, etnoloogid, aga ka keele- ja kunstiinimesed jt kokku viia, andes aimu, kes millega üldse tegeleb, missugust materjali kogutakse ja missugustele küsimustele uurijad välitööde käigus vastust otsivad. Välitöid väga erinevatest aspektidest valgustavad on olnud viimaste aastate Akadeemilise Rahvaluule Seltsi kogumiskonverentsidel lahatud teemad: "Eetika ja valikud" (2011), "Pildi sisse minek" (2012), "Välja piiritlemine: kus kohtuvad uurija ja uuritav?" (2013), "Kehalisus ja tunded välitööde kontekstis" (2014), "Välitööd ajaskaalal" (2015), "Välitööd ja konfliktid" (2016), "Välitööd väärtuste skaalal" (2017).

Idee koostada välitöödele pühendatud artiklikogumik sündiski seoses kahe esimesena nimetatud konverentsi korraldamisega. Plaanist teostuseni läks aega, kaastööd kogunesid aegamööda ja vahepeal jõudis ilmuda Tartu Ülikooli eesti ja võrdleva rahvaluule 
osakonna folkloristide kirjutatud õpik "Folkloristlikud välitööd" (2017), mis võtab kokku ja käsitleb täiesti uuel tasemel välitöid ja laia skaalat nendega seotud valdkondi.

Käesolevasse kogumikku on koondatud seitse erinevatest aspektidest välitöid käsitlevat artiklit. Tõsiasi on, et meie ajaloolised rahvaluulekogud on kujunenud mitmetest erinevatest ideoloogiatest, aga ka poliitikast mõjutatuna ning suunatuna. Nende asjaolude teadmine on tänapäevalgi oluline nii allikakriitikas kui ka erinevate aegade tekstidega töötamisel. Liina Saarlo artikkel rahvaluule kogumisest Alutagusel 1950. aastatel toob esile selle, kuidas Nõukogude Eesti totalitaarne kord püüdis teadust oma ideoloogiate kinnitamiseks ära kasutada, propageerides koguma ja uurima vene rahva folkloori, näiteks otsima rahvuste ajaloolisi seoseid läbi Kalevipoja ja Dobrõnja eepiliste kangelaste lugude. Tollased folkloristid ei saanud valida aega, kuhu nad olid sündinud ja millal oma tööd tegid, ning vajadus kompromissideks oli nende igapäevane tegelikkus.

Siberisse asunud eestlaste uurija Anu Korbi artikkel toob välitööde kogumiskonteksti kirjeldades esile selle, kuidas poolsajandi jooksul on muutunud ja taandunud Siberi eestlaste rahvameditsiin. Nõukogude ajal mõjutas kogumistööd suhtumine Ida-Siberi Minussinski piirkonna eestlaste üldiselt laialt levinud ebausu praktikatesse kui millessegi ideoloogiliselt sobimatusse. 1990. aastail oli see traditsioon veel elav ja üldine ning seda võis ilma piiranguteta koguda. Viimased paarkümmend aastat on aga ravitsemistraditsioon taandumas, sest vananevates külades pole nooremaid, kes nendest oskustest huvitatud oleksid.

Ajaloolase Kalev Jaago ja folklorist Tiiu Jaago artikkel pakub sissevaate Maidla küla pere- ja kohapärimusse. Käsitledes välitööd ning tööd arhiivis osana uurimisprotsessist arutletakse selle üle, kuidas aja jooksul ja erinevate lähenemisnurkade (ajalooline, folkloristlik) kaudu kujundatakse ühe piirkonna materjalikogu.

Folkloristide kogumispäevikutest leiab märkmeid välitöödel kujunenud intiimsemate olukordade kohta, samuti suhtlusest informantidega, kui kõne all on väga isiklikud keha ja seksuaalsust puudutavad teemad. Ometi ei ole neil teemadel seni eriti avatult arutletud. Andreas Kalkun võtab intrigeeriva pealkirjaga artiklis "Informandiga voodis" enesekohaselt ja üldisemalt vaatluse alla just need teemad. 
Vahel võib keeruline poliitiline olukord välitööde piirkonnas otseselt mõjutada suhteid intervjueeritavatega ning sundida kogujat juurdlema oma positsiooni ja ka poliitika üle üldisemas plaanis. Etnoloog Aivar Jürgensoni artiklis jutustatakse just nendest probleemidest, kus nn suur poliitika on pääsenud mõjutama nii kogukondade (loe: rahvuste) vahelisi suhteid, aga ka teadlase ja erinevate kogukondade vahelisi suhteid Abhaasias ja Gruusias.

Kogumiku kaks viimast artiklit on keskendunud välitöödele internetis. Kuigi materjali kogumine internetist tundub olevat palju lihtsam kui füüsiliselt kuhugi sõites ja inimestega suheldes, kehtivad siin seadused ja eetikanõuded, mis seavad oma kindlad piirid. Selleks, et jälgida ja kirjeldada mingit internetikogukonda selle tegevuse, postituste ja materjali järgi, on uurijal otstarbekas osaleda uuritava kogukonna liikmena. Nii on Mare Kalda aastaid ise osalenud infotehnoloogia abil mängitavas aardeotsimismängus, jälgides ühtlasi mängijate suhtlust ning internetileheküljele geopeitus.ee postitatavat pärimusloolist, etnograafilist jms materjali. Oma artiklis arutleb autor selle üle, kuivõrd see mängu käigus pärimusrühma enda aastate jooksul loodud materjal on juba valmis pärimusarhiiv ning vääriks sellisena ka tsentraalset arhiveerimist.

Katrin Tiidenbergi käsitluses keskendutakse sellele, kuidas luua usaldusväärseid suhteid ühes interneti kogukonnas, et koguda andmeid oma uurimistööks. Selleks on uurija teinud mitme aasta vältel osalusvaatlusi internetikeskkonnas Tumblr.com paiknevas enesepildistajate kogukonnas.

Võib tõdeda, et laias plaanis pole välitööde sisu ju muutunud. Muutunud on see, et reflekteerimine ja mõtestamine on saanud tänapäevaste välitööde osaks ning välitööd ei ole ainuüksi kogumine, vaid juba ka esimene etapp uurimistöös. Kogumikus avaldatud artiklid välitööde ajaloost kuni tänapäevaste välitöödeni internetis toovad esile ka muutunud rõhuasetuse, nii nagu ka Lauri Honko seda protsessi kirjeldas. Nimelt tänapäevased välitööd asetavad informandi samale tasemele uurijaga, põhimõtteliselt võrdõiguslikuks uurimisainese tootjaks (Honko 1998, 60). 


\section{Kirjandus}

Arukask, Madis \& Jaago, Tiiu \& Järv, Risto \& Metsvahi, Merili \& Pilt, Maili \& Elo-Hanna Seljamaa \& Siim, Pihla Maria \& Västrik, Ergo-Hart 2017. Folkloristlikud välitööd. Tartu Ülikooli Kirjastus.

Honko, Lauri 1998. Folklooriprotsess. - Mäetagused 6, 56-84 (doi: 10.7592/ MT1998.06.honko).

Kolk, Udo \& Laugaste, Eduard 1963. Rahvaluule välipraktika. Tartu Riiklik Ülikool.

Siikala, Anna-Leena 2007. The Long Road of Folkloristics. - FF Network for the Folklore Fellows, No 33, December 2007, 2. 


\section{PILDI SISSE MINEK. Artikleid välitööde alalt}

\section{Koostanud ja toimetanud EDA KALMRE}

http://www.folklore.ee/rl/pubte/ee/cf/pildisisse

ISBN 978-9949-586-93-6

DOI $10.7592 / \mathrm{TF} 11$

Tartu 2019

Trükis ilmunud:

Pildi sisse minek. Artikleid välitööde alalt.

Tänapäeva folkloorist 11. Tartu 2019

Sarja peatoimetaja: Eda Kalmre

Kogumiku koostaja ja toimetaja: Eda Kalmre

Keeletoimetaja: Asta Niinemets

Kaanekujundus: Artur Kuus

Küljendus: Diana Kahre

Veebiväljaanne: Diana Kahre

Trükitud Eesti Kultuurkapitali toetusel. Väljaande valmimine on seotud Euroopa Liidu Euroopa Regionaalarengu Fondi (Eesti-uuringute Tippkeskus) ja Eesti Haridus- ja Teadusministeeriumi uurimisprojektiga IUT 22-5. Väljaande valmimist on toetanud Akadeemiline Rahvaluule Selts.

E-raamatu valmimist toetas: EKKM14-344 Eesti keele, kultuuri ja folkloori kasutusalade laiendamine ja tutvustamine elektroonilistel infokandjatel.

(C) Eesti Kirjandusmuuseum 2019

(C) Eda Kalmre ja autorid

(C) Artur Kuus 